\title{
First report of apple mosaic virus in peach in Pakistan
}

\section{Azhar UI Islam ${ }^{1} \cdot$ Muhammad Wahaj Javed ${ }^{1} \cdot$ Muhammad Akram $^{1} \cdot$ Javed Rahman $^{2} \cdot$ Muhammad Tahir $^{1}$. Muhammad Farooq Hussain Munis ${ }^{3}$. Abu Bakr Umer Farooq ${ }^{1}$}

Received: 8 January 2020 / Accepted: 28 July 2020 / Published online: 5 August 2020

(C) Società Italiana di Patologia Vegetale (S.I.Pa.V.) 2020

Keywords ApMV, Peach, Pakistan

Peach (Prunus persica) is one of the most important economic temperate fruits cultivated in Pakistan. Apple mosaic virus (ApMV; genus Ilarvirus, family "Bromoviridae") is one of more than 30 viruses that can infect peach trees, worldwide. It may cause yellow line patterns on leaves and infection can result in severe fruit quality and yield losses (Paunovic et al. 2011). A survey of peach orchards in the Swat region of Pakistan was conducted to assess ApMV incidence and samples were collected from 200 symptomatic trees. Total RNA was extracted from $100 \mathrm{mg}$ cortical scrapings of dormant shoots using a protocol of Chang et al. (1993) and tested for ApMV by two step RT-PCR using random hexamers to reverse transcribe RNA and the primers described by Menzel et al. (2002) to detect ApMV during PCR. The expected 262 bp-long fragment was obtained from $34 / 200$ samples and the detections were confirmed using the ApMV species specific primer pair ApMV-F (5'CTGGatgCAagtgGtGTC-3') and ApMV-R (5'AATCCCTCATAAAGACTTTCG-3'), which were designed for this study and targeted a 548 nucleotide partial coat protein (CP) gene region. The PCR products of five samples were purified and sequenced and since the obtained sequences were identical, only two were submitted to GenBank (accession Nos. MN861387, MN861388). The nucleotide sequences of the $\mathrm{CP}$ gene fragment of peach isolates from this study shared
98.15\% sequence similarity with isolate ApMV ISO5_EX/ GARD (LT574870) and isolate Pospeh (HG328270) from Czech Republic and Belarus, respectively. To our knowledge, this is the first report of ApMV detection in peach trees in Pakistan.

Acknowledgements This work funded by Higher Education Commission, Pakistan, through the National Research Program for Universities (NRPU) under the project NRPU 5403: "Viral sanitary status of temperate fruits (grapes, pome fruits, stone fruits, etc.) in Pakistan".

\section{References}

Chang S, Puryear J, Cairney J (1993) A simple and efficient method for isolation RNA from pine trees. Anal Biochem 360:318-320

Menzel W, Jelkmann W, Maiss E (2002) Detection of four apple viruses by multiplex RT-PCR assays with coamplification of plant mRNA as internal control. J Virol Methods 99:81-92

Paunovic S, Pasquini G, Barba M (2011) Apple mosaic virus in stone fruits. In: Hadidi A, Barba M, Candresse T, Jelkmann W (eds) Virus and virus like diseases of pome and stone fruits, Chapter 18. The American Phytopathological society press, St. Paul, pp 91-95

Publisher's note Springer Nature remains neutral with regard to jurisdictional claims in published maps and institutional affiliations.
Abu Bakr Umer Farooq

abbubakr@hotmail.com

1 Department of Environmental Sciences, COMSATS University, Islamabad, Vehari Campus, Vehari, Pakistan

2 Agricultural Research Institute, Mingora, Swat, KP, Pakistan

3 Department of Plant Sciences, Quaid-e-Azam University, Islamabad, Islamabad, Pakistan 